\title{
THERMAL INJURIES: THE EFFECTS OF FREEZING
}

\author{
By HENRY N. HARKINS AND PAUL H. HARMON \\ (From the Department of Surgery, The University of Chicago, Chicago)
}

(Received for publication November 9, 1936)

The problem of freezing will be considered from two standpoints: first, the local lesion and the therapeutic management of the frozen member, and second, the general effects of freezing including the possible presence of secondary shock and depression of the general body temperature. The literature on freezing as compared with burns is not very extensive. This may be accounted for by the fact that burns are caused by agents of civilization, while freezing usually occurs in outof-the-way places. It is thus essentially indigenous to localities where medical attention is scant, and except for such rare instances as Beaumont (and Dafoe), empiric rather than physiological observations are made.

\section{Local treatment of a frozen member}

One item in the conventional treatment of frozen limbs is the vertical suspension of the limb, especially as practiced by Bergmann (1), König (1) and Selenkoff (1), and discussed by Douglas (3). These authors thought that the viability of the limb is aided by this method. No experiments were performed to test this conclusion. It is possible that one of the factors in frost-gangrene is the compression of the vessels by local swelling, and this could conceivably be aided by vertical suspension. It is interesting to note, however, that vertical suspension is contraindicated in most other forms of impending gangrene as was pointed out by Barney Brooks (4) and others.

A second method in the accepted treatment of freezing is the use of multiple incisions, as applied by Bundschuh (5) and Wittek (6) in 1915. These incisions probably are of value in reducing the local swelling with its resultant pressure on vessels and hence are of value to the viability of the limb. It is to be remembered, however, that the escape of this fluid, while it may be of benefit to the limb, may be a menace to the life of the organism as a whole when severe shock is present.
No experiments were performed to test the efficacy of the incision treatment.

\section{Effects of gradual and rapid thawing of frozen tissues}

One of the original purposes of the present work was to test the time-honored conception that a frozen limb must not be thawed out too quickly. No satisfactory physiological support for this empirically adopted custom has been offered. Some observers attribute the danger of sudden thawing to the release of thrombi. Nägelsbach (7) states, however, that he finds neither clinical nor experimental support for this view and that during the World War, the surgeons who adopted the practice of heating frozen limbs as rapidly as possible had at least no poorer results than the others.

In our experiments, both hind limbs of thoroughly anesthetized dogs were frozen stiff by the application of solid carbon dioxide. The legs were not dissected to determine the depth of this freezing, but the joints would not bend and it was believed the legs were frozen entirely through. Then one limb was placed in water at $42^{\circ} \mathrm{C}$. for about 20 minutes when thawing was complete and the other in ice water at about 2 to $12^{\circ} \mathrm{C}$. for an hour at the end of which time it too had thawed. In the ensuing 18 hours the subsequent behavior of the limbs including reactive hyperemia, restoration of circulation, and secondary swelling was identical.

Both ears of thoroughly anesthetized rabbits were similarly frozen. The amount of freezing was enough so that when thawing was done at room temperature about one-third of the ears would become gangrenous during the next ten days. In a series of eight rabbits one ear was thawed at $38^{\circ} \mathrm{C}$. and the other at $2^{\circ} \mathrm{C}$. over a period of ten minutes and the ears observed over a period of more than a month. The amount of swelling and subsequent gangrene was essentially similar on the two sides. If anything, the ears 
that were thawed in ice water showed a trace more gangrene.

\section{Relative effects of freezing by different methods}

Freezing may occur from exposure to cold air, ice and snow, brine $\left(-40^{\circ}\right.$ C. $)$, liquid air $\left(-140^{\circ}\right.$ C. $)$, solid carbon dioxide ( $-79^{\circ}$ C.) and ethyl chloride. Changes observed clinically following these various types of injury are essentially similar and include freezing of the part followed by reactive hyperemia, edema, bleb formation, and in some cases gangrene. All of the experiments reported in this paper were performed using solid carbon dioxide. The clinical similarity between all types of freezing may be an answer to those who, noting the resemblance between solid carbon dioxide freezing and burns, apply $a$ posteriori reasoning and infer that the carbon dioxide produces a burn.

\section{Insulating effects of living tissues}

Thermometers were placed in the axillae of 4 dogs, and solid carbon dioxide applied to the surface over the buried thermometer. The average drop in temperature in the first minute was $11^{\circ} \mathrm{C}$. when the thermometer was placed subcutaneously, and only $0.2^{\circ} \mathrm{C}$. per minute over the first $10 \mathrm{~min}$ ute period when the thermometer was placed $2 \mathrm{~cm}$. below the surface. In all instances the skin became solidly frozen before the deep thermometric reading had fallen more than a degree. In one instance at a depth of $2 \mathrm{~cm}$. it took 17 minutes and in another 7 minutes for the local temperature to drop $10^{\circ} \mathrm{C}$. (a $10 \mathrm{~cm}$. cube of solid carbon dioxide being pressed tightly against the shaved skin). If the measuring thermometer was placed subcutaneously, about 2 minutes' application was necessary to produce a drop in temperature of $10^{\circ} \mathrm{C}$. in this particular animal. It was found that living tissue was a much better insulator than dead tissue.

\section{General changes in body temperature following local freezing}

In animals in which portions of one lateral half of the body were frozen, the rectal temperature was recorded. In animals in which both hind limbs were frozen, the body temperature was de- termined by inserting a thermometer deep into the muscles through the tracheotomy wound. All of the dogs showed a slight fall in body temperature, but only five fell below $30^{\circ} \mathrm{C}$. The lowest temperature recorded was $24.1^{\circ} \mathrm{C}$. $\left(75.4^{\circ} \mathrm{F}\right.$.), two hours and forty minutes after beginning the application of ice. Three hours later it had risen to $35^{\circ} \mathrm{C}$. $\left(95^{\circ} \mathrm{F}\right.$.), but fell to $32.1^{\circ} \mathrm{C}$. $\left(89.8^{\circ} \mathrm{F}\right.$.) three hours later at which time the dog was bled to death in order to observe the effect on bleeding volume (see below). Temperatures in the other four animals reached low levels, $25.7^{\circ} \mathrm{C}$. $\left(78^{\circ} \mathrm{F}\right.$.) 16 hours before death, $25.6^{\circ}$ C. $\left(78^{\circ}\right.$ F.) six hours before death by bleeding, $27^{\circ} \mathrm{C}$. $\left(80.6^{\circ} \mathrm{F}\right.$.) three hours before death, and $24.7^{\circ} \mathrm{C}$. $\left(76.5^{\circ} \mathrm{F}\right.$.) one hour before death by bleeding. The course of the temperature readings in four of these animals is shown in Figure 1.

Reincke (8) in 1875 reported a very interesting series from Hamburg, of 17 drunken men exposed to extreme cold while intoxicated. On admission to the hospital all 17 had markedly lowered rectal temperatures. All of the 12 patients with temperatures that did not fall below $30^{\circ} \mathrm{C}$. $\left(86^{\circ}\right.$ F.) recovered. Five patients had temperatures that went below $30^{\circ} \mathrm{C}$., two of whom recovered. One patient had a temperature of $28.4^{\circ}$ C. $\left(83.1^{\circ}\right.$ F.) 8 hours before death. Another had a temperature of $30^{\circ} \mathrm{C}$. $\left(86^{\circ} \mathrm{F}\right.$.) and recovered. Another case had $27^{\circ}$ C. $\left(80.6^{\circ}\right.$ F.) with death 13 hours later. The most striking case in Reincke's series, however, was that of a 34 year old laborer who was admitted with a temperature of $24^{\circ} \mathrm{C}$. $\left(75.2^{\circ} \mathrm{F}\right.$.). Four hours later the temperature was only $27.4^{\circ}, 10$ hours later only $32.6,23$ hours later $37.8^{\circ} \mathrm{C}$., and on the following day he was discharged completely well. This is the lowest known recorded temperature in a human being with recovery. Sonnenburg and Tschmarke (2) have collected reports of other instances of hypothermia.

Although dogs are perhaps somewhat more poikilothermic than human beings, the temperature of $24.1^{\circ} \mathrm{C}$. $\left(75.4^{\circ} \mathrm{F}\right.$.) in one of our dogs six hours before death by bleeding is of interest. One of the writers (H. N. H.) has seen a case of enormous hydrocephalus (head $75 \mathrm{~cm}$. in circumference) in a child aged 8 months in which the rectal temperature on admission was $36.7^{\circ} \mathrm{C}$. 


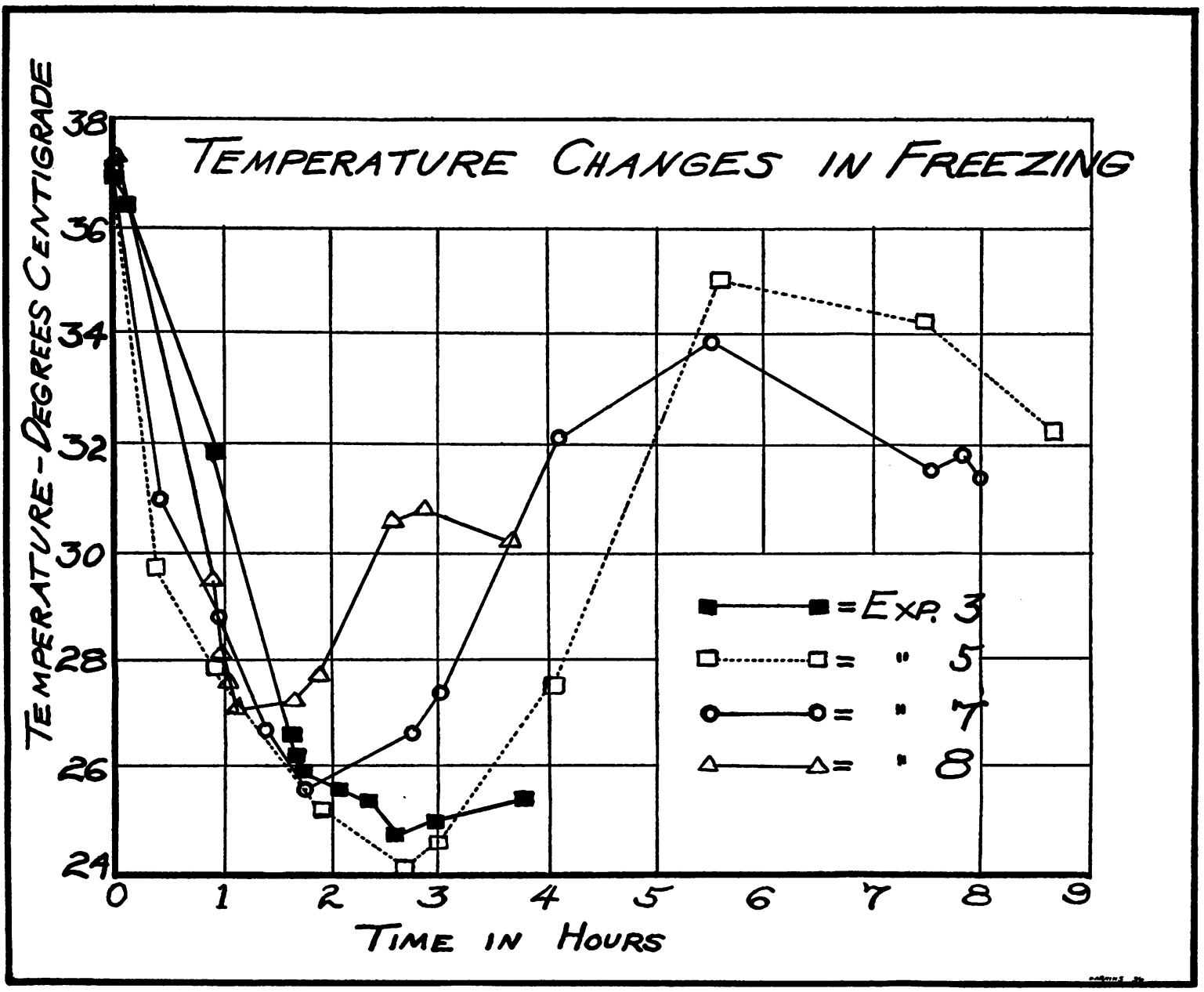

Fig. 1. Temperature Changes in Freezing

Dogs 3, 5 , and 7 were bled at the termination of the experiment; Dog 8 died. The freezing was induced by application of solid carbon dioxide to the posterior portion of the body, and the temperatures are taken by a thermometer inserted deep into the muscles of the neck and chest. The freezing was usually done over a period of one to two hours.

$\left(98^{\circ} \mathrm{F}.\right)$, the next day was $27.5^{\circ}$ C. $\left(81^{\circ} \mathrm{F}\right.$.) over a four hour period, the third day was $28.0^{\circ}$ C. $\left(82^{\circ} \mathrm{F}\right.$.) and then rose gradually to $36.6^{\circ} \mathrm{C}$. $\left(98^{\circ} \mathrm{F}\right.$.) six days after admission when death occurred following spontaneous rupture of the hydrocephalus. Among the lower animals, references are made to transition stages between the poikilothermic condition of the cold-blooded animals and the homothermic state of the higher mammals and birds, in which a constant body temperature is maintained in spite of wide fluctuations in the temperature of the environment. Baldwin (9) has shown that reptiles are not completely cold-blooded. The classic observations of
Kredel (10) on the variations of a representative of the lower mammals, the three-toed sloth, Bradypus cuculliger cuculliger Wagler, are of great fundamental importance. This author has carefully recorded the temperature variations of this animal and has shown that the temperature of the air is the chief factor in determining that of the sloth. Some primitive heat regulation comes from within, however.

These experiments are of interest in showing that even in the higher mammals the internal regulation of general body temperature may not entirely control the situation under great stress. This applies equally well to other body functions, 
for example the $\mathrm{pH}$ of the blood serum. This was formerly thought to remain quite constantly at 7.40 but has been shown to fall to as low as 6.12 under certain temporary conditions (19).

\section{Secondary shock in freezing}

It has been shown $(11,12,13)$ that in burns there is a marked loss of blood plasma-like fluid from the circulating blood stream into the burned tissues. This plasma loss is associated with a marked blood concentration, fall in blood pressure, lowered bleeding volume and changes suggestive of secondary shock. No reports of shock in freezing were found in the literature, and it was thought advisable to test whether freezing and burning might not produce similar changes. With this in mind the experiments discussed in the following sections were performed.

\section{Changes in concentration of blood}

In shock in human beings resulting from severe burns, Underhill et al. (14) found that hemoglobin readings as high as 209 per cent indicated a marked blood concentration. Blalock (11) found that in experimental burns the hemoglobin may rise to 130 per cent. One of the writers (13) found that in experimental burns the hemoglobin may rise to as high as 162 per cent (Sahli : 17 grams per $100 \mathrm{cc} .=100$ per cent) and the hematocrit reading to 72 per cent.

Since blood concentration is a regular accompaniment of shock due to burns, it was thought that a similar blood concentration might be present in shock due to freezing. Solid carbon dioxide was applied to about one-fourth of the body surface of 10 completely anesthetized dogs and left in place for about an hour, at the end of which time the underlying tissues were deeply frozen. Frequent blood pressure readings, hemoglobin percentages and hematocrit readings were determined. The blood pressure was obtained by placing in the carotid artery a cannula which was connected to a mercury manometer. Hemoglobin determinations were made by the Sahli method and hematocrit readings with the Van Allen hematocrit.

Results. Usually at the end of about 18 to 24 hours the blood pressure fell rather rapidly to an average of about $80 \mathrm{~mm}$. $\mathrm{Hg}$. The changes in blood concentration began almost immediately after the freezing and were present long before the blood pressure had fallen markedly. It is seen from Table I that in all animals there was an

TABLE I

Changes in blood concentration in shock due to freesing (the figures recorded after freesing indicate the highest readings in each experiment)

\begin{tabular}{c|c|c|c|c}
\hline \hline \multirow{2}{*}{ Experiment } & \multicolumn{2}{|c|}{ Hemoglobin } & \multicolumn{2}{|c}{ Hematocrit } \\
\cline { 2 - 5 } & Control & After freezing & Control & After freezing \\
\cline { 2 - 5 } & per cent & per cent & & \\
1 & 76 & 131 & 36 & 63 \\
2 & 75 & 136 & 37 & 59 \\
3 & 102 & 113 & 48 & 58 \\
4 & 93 & 104 & 46 & 53 \\
5 & 104 & 160 & 48 & 74 \\
6 & 97 & 128 & 46 & 63 \\
7 & 123 & 159 & 61 & 74 \\
8 & 85 & 116 & 42 & 61 \\
9 & 96 & 163 & 50 & 70 \\
10 & 109 & 168 & 54 & 80 \\
\hline Average & 96 & 134 & 47 & 66 \\
\hline
\end{tabular}

increase in hemoglobin percentage and hematocrit reading. The average hemoglobin percentage before freezing was 96 and after freezing was 134 . The average hematocrit reading before freezing was 47 and after freezing was 66 . The figures obtained in Experiment 10 (Table I) are higher than in any readings obtained in shock due to burns, except by Underhill in human beings. Control experiments showed no marked blood concentration (13).

Conclusion. There is a marked blood concentration in shock following freezing which is similar in degree to the blood concentration present in shock due to burns. This blood concentration begins before a marked fall in blood pressure occurs and is hence of value in predicting the onset of shock.

\section{Shift of body fluids}

It has been shown by Blalock (11), Underhill et al. (12) and the writer (13) that in shock due to severe burns there is a loss of fluid from the blood stream into the burned tissues. It is considered by these authors that this loss of fluids is responsible for a large part of the shock resultant to burns. The amount of fluid shift into the tissues has been measured by burning one lateral 
half of an animal and then after careful saggital bisection, comparing the weight of the burned and unburned sides (11); by weighing the fluid expressed from the water-logged burned tissues (12) ; and by burning one lateral half of an animal placed on a balanced apparatus and measuring the amount of displacement caused by the increase in weight of the burned side (13).

It was thought that the severe general effects of freezing a portion of the body might be due to a similar leakage of fluid from the blood stream into the frozen or thawing tissues. Portions of one lateral half of 9 completely anesthetized dogs were frozen by the direct application of solid carbon dioxide for about one hour. After a period averaging 21 hours from the time of freezing, 4 of the dogs were dead and the rest were killed. The initial blood pressure in the 9 dogs averaged 147 and the final blood pressure $81 \mathrm{~mm}$. $\mathrm{Hg}$. This amount of blood pressure lowering may be considered as arbitrarily within the limits of so-called surgical shock. The animals were then carefully bisected by the method previously described (13) and a comparison made of the weights of the frozen and unfrozen sides. The average difference amounted to 2.55 per cent of the total body weight. Incision into the tissues that had been frozen revealed sufficient plasmalike fluid to account for the difference in weight. This amount of plasma, if lost from the blood stream, is sufficient to account for a large part of the shock present in these animals (11). In 8 experiments on burns previously reported (13), the amount of fluid shift at death was 2.2 per cent of the total body weight. Control experiments are listed in this previous paper.

Conclusion. After freezing, there is a considerable loss of fluid from the blood stream into the frozen tissues. The amount of this fluid shift is similar to that in severe burns and is sufficient to account in part at least for the resultant shock.

\section{Composition of edema fluid}

The composition of the fluid that escapes into the subcutaneous tissues after burns has been determined by Beard and Blalock (15). These authors found that, in general, the chloride content of the fluid was higher than that in blood plasma, the concentration of sugar and nonprotein nitro- gen was approximately the same in the 2 media and the protein content of the subcutaneous fluid was about 20 per cent lower than that of the blood plasma. Underhill and Fisk (16) made similar comparisons between the tissue fluid after burns and the blood serum. Their results agree in general with those of Beard and Blalock, except that they found the nonprotein nitrogen content considerably higher in the edema fluid than in the blood serum.

TABLE II

Shift of body fluids in shock due to freezing

\begin{tabular}{|c|c|c|c|c|c|}
\hline \multirow{2}{*}{ Experiment } & \multirow{2}{*}{$\begin{array}{l}\text { Weight } \\
\text { of dog }\end{array}$} & \multirow{2}{*}{$\begin{array}{l}\text { Duration } \\
\text { of experi- } \\
\text { ment* }\end{array}$} & \multicolumn{2}{|c|}{ Blood pressure } & \multirow{2}{*}{$\begin{array}{c}\text { Shift of } \\
\text { body fluid } \\
\text { as percent- } \\
\text { age of body } \\
\text { weight }\end{array}$} \\
\hline & & & Initial & Final & \\
\hline $\begin{array}{l}1 \\
2 \\
3 \\
4 \\
5 \\
6 \\
7 \\
8 \\
9\end{array}$ & $\begin{array}{r}\text { kgm. } \\
12.2 \\
13.8 \\
16.0 \\
7.3 \\
8.9 \\
11.1 \\
11.0 \\
8.3 \\
7.1\end{array}$ & $\begin{array}{c}\text { hours } \\
26 \\
28 \\
26 \\
17 \\
20 \\
25 \\
17 \\
13 \\
18\end{array}$ & $\begin{array}{c}\text { mm. } H_{\boldsymbol{B}} \\
160 \\
138 \\
164 \\
156 \\
118 \\
168 \\
159 \\
120 \\
142\end{array}$ & $\begin{array}{c}\text { mm. } H \boldsymbol{g} \\
114 \\
92 \\
96 \\
94 \\
42 \\
70 \\
38 \\
64 \\
120\end{array}$ & $\begin{array}{c}\text { per cent } \\
5.14 \\
0.15 \\
2.44 \\
1.51 \\
4.05 \\
2.92 \\
2.77 \\
1.35 \\
2.59\end{array}$ \\
\hline Average & 10.6 & 21 & 147 & 81 & 2.55 \\
\hline
\end{tabular}

* The duration of the experiment indicates the time of death of the animal after freezing. The animals in Experiments 1, 2, 3, 4 and 8 were killed immediately following the last blood pressure reading; the animals in the other experiments died sometime following the last reading. The lateral shift of body fluids is determined by the bisection method.

The results of these authors indicated that the fluid that escapes into the subcutaneous tissues after burns very closely resembles blood plasma. The escape of a plasma-like fluid undoubtedly produces more serious consequences than the escape of a simpler solution. Hence, it was considered of importance to determine whether the fluid that escapes into the subcutaneous tissues in large amounts after freezing is of a plasma-like nature similar to that following burns. Nine completely anesthetized dogs in which shock was produced by freezing portions of the body with solid carbon dioxide were dissected after death and large amounts of edematous subcutaneous tissue found. By making multiple incisions in this tissue, sufficient fluid drained out for analysis. This fluid was only slightly tinged with blood, but clotted if no anticoagulant was added. A similar 
amount of anticoagulant was added to the edema fluid and to a sample of blood obtained from the carotid artery. Analyses were made of the fluid and of the blood plasma. The sugar was determined by the Folin modification method on a sulfate-tungstate filtrate $(20)$; the sodium chloride by the Eisenman open-Carius method (21); the protein by the Koch-McMeekin micro-Kjeldahl method (22); and the nonprotein nitrogen by the same method on a Folin-Wu filtrate.

TABLE III

A comparison of the concentration of certain substances in blood plasma and in the fluid that escapes into the subcutaneous tissues after freezing

\begin{tabular}{|c|c|c|c|c|c|c|c|c|}
\hline \multirow{2}{*}{$\begin{array}{c}\text { Experi- } \\
\text { ment }\end{array}$} & \multicolumn{2}{|c|}{ Sugar } & \multicolumn{2}{|c|}{$\mathrm{NaCl}$} & \multicolumn{2}{|c|}{$\begin{array}{c}\text { Nonprotein } \\
\text { nitrogen }\end{array}$} & \multicolumn{2}{|c|}{ Protein } \\
\hline & Plasma & Fluid & Plasma & Fluid & Plasma & Fluid & Plasma & Fluid \\
\hline $\begin{array}{l}1 \\
2 \\
3 \\
4 \\
5 \\
6 \\
7 \\
8 \\
9\end{array}$ & $\begin{array}{c}\text { mgm. } \\
\text { per } \\
100 \\
c c . \\
\\
132.5 \\
\\
44.1 \\
90.1 \\
84.0 \\
94.2 \\
177.8\end{array}$ & \begin{tabular}{|c} 
mgm. \\
per \\
100 \\
$c c$. \\
95.2 \\
101.0 \\
81.0 \\
98.0 \\
13.4 \\
18.9 \\
$*$ \\
111.1 \\
82.1
\end{tabular} & $\begin{array}{l}673.9 \\
654.0 \\
700.8 \\
709.0 \\
663.4 \\
655.2\end{array}$ & $\begin{array}{c}\text { mgm. } \\
\text { per } \\
100 \\
c c . \\
711.4 \\
665.7 \\
758.2 \\
688.0 \\
665.7 \\
703.2 \\
703.2 \\
690.3 \\
686.8\end{array}$ & $\begin{array}{c}\text { mgm. } \\
\text { per } \\
100 \\
c c . \\
\\
40.0 \\
\\
56.8 \\
95.4 \\
27.0 \\
45.5 \\
60.3\end{array}$ & \begin{tabular}{|c|} 
mgm. \\
per \\
100 \\
$c c$. \\
38.5 \\
35.3 \\
36.8 \\
50.8 \\
76.3 \\
33.3 \\
60.6 \\
44.2 \\
73.2
\end{tabular} & $\begin{array}{c}\text { grams } \\
\text { per } \\
100 \\
c c . \\
\\
4.4 \\
\\
3.3 \\
3.7 \\
4.8 \\
5.1 \\
3.4 \\
4.6\end{array}$ & \begin{tabular}{|c} 
grams \\
per \\
100 \\
$c c$. \\
3.9 \\
2.9 \\
3.2 \\
3.3 \\
3.8 \\
3.6 \\
3.4 \\
4.7 \\
3.7
\end{tabular} \\
\hline Average & 103.8 & 66.7 & 676.1 & 696.9 & 54.2 & 49.9 & 4.2 & 3.6 \\
\hline
\end{tabular}

* The value for the sugar in the fluid in Experiment 7 was too low to read.

The results of these analyses are shown in Table III. The concentration of sugar is, in general, lower in the fluid than in the blood plasma. The extremely low values in several instances are of interest. The chloride concentration is approximately the same in the blood plasma and tissue fluid. The nonprotein nitrogen and protein are somewhat higher in the plasma than in the tissue fluid.

Patients with frozen ears were observed frequently, and in all instances after thawing a marked swelling was noted. Only one patient with extensive freezing injury was observed in this study. This patient, ${ }^{1}$ a woman, aged 43, tried to commit suicide by lying in the snow a night when the temperature was $-22^{\circ} \mathrm{F}$. When

1 I am indebted to Dr. A. J. Rissinger for permission to report this case. found, she was not unconscious but both legs were frozen stiff to just below the knees and when her stockings were removed they came off like wall paper from a plastered wall. She received heat generally and cold compresses to the local lesions. The legs thawed out but the toes of both feet and sole of the left foot remained very cyanotic. Later gangrene developed in the toes of the left foot. The blood pressure was normal and there was no blood concentration. One of the chief points of interest with regard to this patient was the extensive swelling and blistering of the frozen legs. This is shown to some extent in Figure 1 which was taken after the largest blister had broken. The blister fluid was somewhat similar to blood plasma on chemical analysis, the total protein being 3.0 grams per $100 \mathrm{cc}$, the albumin:globulin ratio 2.2 , and the nonprotein nitrogen, sugar, and sodium chloride being 26.0, 87.0 , and $643.5 \mathrm{mgm}$. per $100 \mathrm{cc}$. respectively. One blister contained $40 \mathrm{cc}$. of this fluid and two other blisters were larger. Measurement of the limbs 36 hours after freezing showed that the volume of the left was greater than the right by approximately $850 \mathrm{cc}$. Since the right leg was also swollen, this figure may not represent the entire extent of the swelling. Although the plasma loss in this patient was not sufficient to produce shock, it indicates what might happen from freezing of a larger area.

Conclusion. The composition of the edema fluid that escapes into the subcutaneous tissues after freezing is quite similar to blood plasma. This indicates that the loss of large amounts of such plasma-like fluid from the blood stream might account, in part at least, for the shock resultant to the freezing. The important difference between the edema fluid produced by freezing and ordinary edema fluid is the high protein content of the former. The rapidity of the loss of this fluid is also of significance.

\section{Bleeding volume}

The bleeding volume in control dogs was found to be $\mathbf{5 8 . 6}$ per cent of the calculated blood volume (one-thirteenth of the body weight) by Roome, Keith, and Phemister (17) and 53.4 per cent by Harkins (13). On the other hand, the former authors found that in shock due to trauma to an 




Fig. 2. Blisters and Swelling of Legs Existing 36 Hours after Freezing

Both legs were swollen but only the blisters on the left side are well visualized, and the largest of these ruptured before the picture was taken.

extremity, hemorrhage, plasmapheresis, and intestinal manipulation, the bleeding volume was greatly reduced, averaging 21.8 per cent, and in burns the latter author found it to average 20.3 per cent. In another series of experimental burns it was found that in 6 burned animals in which the blood pressure was allowed to fall near a so-called shock level ( 50 to $82 \mathrm{~mm}$. $\mathrm{Hg}$ ) before the bleeding volume was determined, the bleeding volume averaged 26.3 per cent. If, however, the bleeding was done before the blood pressure had fallen markedly (102 to $130 \mathrm{~mm}$. $\mathrm{Hg}$ ), the bleeding volume was already markedly reduced, averaging 31.4 per cent.

The present work was undertaken to determine the bleeding volume in experimental freezing. Portions of the bodies of dogs were frozen by solid carbon dioxide under complete anesthesia (maintained till end of experiment) as described in previous papers (18) and the results shown in Table IV. It is seen that in all instances the bleeding volume was below the normal values.

In three other dogs where the bleeding was
TABLE IV

Bleeding volumes of dogs with experimental freezing

\begin{tabular}{|c|c|c|c|c|c|c|c|c|c|c|}
\hline \multirow{2}{*}{ 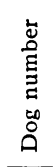 } & \multirow[b]{2}{*}{ 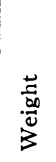 } & \multirow{2}{*}{\multicolumn{2}{|c|}{$\begin{array}{l}\text { Interval } \\
\text { from } \\
\text { freezing to } \\
\text { bleeding }\end{array}$}} & \multicolumn{2}{|c|}{$\begin{array}{c}\text { Blood } \\
\text { pressure }\end{array}$} & \multicolumn{2}{|c|}{$\begin{array}{l}\text { Hemo- } \\
\text { globin }\end{array}$} & \multicolumn{2}{|c|}{$\underset{\text { tocrit }}{\text { Hema- }}$} & \multirow{2}{*}{$\begin{array}{c}\text { Terminal } \\
\text { bleeding } \\
\text { volume }\end{array}$} \\
\hline & & & & 莺 & 节 & 槖 & 离节节 & 节 & 离苞节 & \\
\hline & $\mathrm{kgm}$. & hours & $\begin{array}{c}\min - \\
\text { utes }\end{array}$ & $\underset{\mathrm{Hg}}{\mathrm{mm}}$ & $\underset{H g}{m m}$. & $\begin{array}{c}\text { per } \\
\text { cent }\end{array}$ & $\begin{array}{c}\text { per } \\
\text { cent }\end{array}$ & & & $\begin{array}{l}\text { per cent } \\
\text { calculated } \\
\text { blood } \\
\text { volume }\end{array}$ \\
\hline 1 & 7.0 & 4 & 45 & 172 & 36 & 86 & 100 & 35 & 50 & 27.0 \\
\hline 2 & 7.0 & 15 & 15 & 166 & 72 & 82 & 126 & 39 & 62 & 24.2 \\
\hline 3 & 5.7 & 3 & 45 & 148 & 66 & 88 & 100 & 37 & 42 & 39.0 \\
\hline 4 & 7.4 & 8 & 10 & 154 & 42 & 99 & 167 & 40 & 72 & 7.8 \\
\hline 5 & 6.5 & 9 & 10 & 150 & 82 & 105 & 123 & 43 & 63 & 29.9 \\
\hline \multicolumn{2}{|c|}{ Average } & & & & & & & & & 25.6 \\
\hline
\end{tabular}

done before the blood pressure had fallen markedly (90, 96 and $112 \mathrm{~mm}$. $\mathrm{Hg}$ ) the bleeding volumes averaged 40.5 per cent (43.1, 31.1 and 47.3 per cent respectively). Two other experiments were of great interest where the blood pressure was rapidly lowered by the general effects of cold before there had been time for considerable fluid exudation. In these two experiments the final blood pressures were 78 and $54 \mathrm{~mm}$. $\mathrm{Hg}$, and the 
bleeding volumes determined 2 hours after freezing were 50 and 55 per cent respectively. This indicates that the general effects of cold can reduce the blood pressure before fluid exudation has taken place to any great extent. The fact that at the time of bleeding there were slight local signs of fluid exudation and very little blood concentration also points in this direction. It seems, therefore, that under certain circumstances cold can produce a type of so-called primary shock. If the animal survives this initial period, fluid exudation into the thawing area with blood concentration, lowered bleeding volume and other typical signs of secondary shock ensues.

\section{Pathological studies}

These studies are as yet incomplete. Occasional hemorrhages into the adrenal glands and in one instance a hemorrhage into the duodenal wall, possibly the precursor of a Curling-like ulcer were the chief positive findings remote from the frozen region. At the site of the freezing all blood vessels were found to be patent and no thrombi were found. At the edges of the area the skin was markedly red and injected. In the subcutaneous tissues there was an extensive edema.

\section{COMMENT}

The present work did not help to elucidate the local treatment of a frozen member. Although experiments indicated no difference in the response of dog's legs and rabbit's ears to slow and rapid thawing, the experiments were not conclusive. They did not cover a wide enough variety in extent of freezing and time and rate of thawing, etc. Thus this aspect of the question is still left in abeyance although doubt is cast on the efficacy of the time-honored custom of gradual thawing.

The extreme drop in general body temperature recorded in several of the experiments is of interest. It is quite possible that such low readings may have been influenced by the barbital narcosis, but the restoration of a more normal body temperature in several instances after the removal of the ice augurs against this to some extent. It is quite possible that such low temperatures would not have been obtained if a less severe freezing agent than solid carbon dioxide had been used. These low readings indicate, however, that even the higher mammals may be relatively poikilothermic under certain conditions.

Aside from the general lowering of body temperature, the presence of secondary shock is of interest in freezing. The lowered bleeding volume, the changes in blood concentration including increase in hemoglobin percentage and hematocrit reading, and the marked leakage of plasma-like fluid into the tissues that have been frozen all indicate that there is a similarity between the effects of freezing and burning. Both of these thermal injuries produce a local reaction and resultant secondary shock. Furthermore, the secondary shock following thermal injury is similar to secondary traumatic shock following other types of injury. The similarity in the reaction of the mammalian organism to injury is most apparent when the comparison is made between the different types of thermal injury. Under natural conditions it is difficult to conceive, however, a situation in which enough of the body could be frozen to produce shock without the effect of exposure to cold being an important if not a dominating factor. In burns, on the other hand, extensive local burning without rise in general body temperature is the rule rather than the exception.

\section{SUMMARY AND CONCLUSIONS}

1. In freezing experiments no evidence was found in favor of the empiric practice of gradual thawing of a frozen member.

2. Under certain conditions freezing and cold cause a marked lowering of general body temperature. Citation is made of Reincke's case of a man with a temperature of $24.0^{\circ} \mathrm{C}$. $\left(75.2^{\circ} \mathrm{F}\right.$.) who ultimately recovered, and of one animal in the present study with $24.1^{\circ} \mathrm{C}$. $\left(75.4^{\circ} \mathrm{F}\right.$.) six hours before death by bleeding. These observations indicate that even the higher mammals may have their temperature regulatory mechanism broken down under a sufficiently severe strain.

3. Under experimental laboratory conditions a localized portion of the body may be frozen without a predominant general chilling. Under these circumstances a marked exudation of plasma-like fluid into the local tissues occurs with thawing, resulting in blood concentration, lowered bleeding volume and decrease in arterial blood pres- 
sure. This condition resembles the secondary shock following burns and indicates the similarity in action of different types of thermal injury. Under very special conditions the same might occur in man.

\section{BIBLIOGRAPHY}

1. (a) Bergmann, cited by Sonnenburg and Tschmarke (2).

(b) König, cited by Sonnenburg and Tschmarke (2).

(c) Selenkoff, cited by Sonnenburg and Tschmarke (2).

2. Sonnenburg, E., and Tschmarke, P., Die Verbrennungen und die Erfrierungen, Neue Deutsche Chirurgie, Vol. 17, Ferdinand Enke, Stuttgart, 1915.

3. Douglas, Beverly, Frostbites: Practitioner's Library of Medicine and Surgery, V : D. Appleton-Century Company, New York, 1934, pp. 14 to 17.

4. Brooks, Barney, Pathologic changes in muscle as a result of disturbances of circulation: An experimental study of Volkmann's ischemic paralysis. Arch. Surg., 1922, 5, 188.

5. Bundschuh, Ed., Ueber die Behandlung der Erfrierungen von Fingern und Zehen. München. med. Wchnschr., 1915, 62, 416.

6. Wittek, Arnold, Zur Behandlung der Erfrierungen. München. med. Wchnschr., 1915, 62, 416.

7. Nägelsbach, E., Die Entstehung der Kältegangrän. Deutsche Ztschr. f. Chir., 1920, 160, 205.

8. Reincke, J. J., Beobachtungen über die Körpertemperatur Betrunkener. Deutsches Arch. f. klin. Med., 1875, 16, 12.

9. Baldwin, cited by Kredel (10).

10. Kredel, F. E., Note on the temperature of the sloth. J. Mammology, 1928, 9, 48.

11. Blalock, Alfred, Experimental shock. VII. The importance of the local loss of fluid in the production of the low blood pressure after burns. Arch. Surg., 1931, 22, 610.

12. Underhill, F. P., Kapsinow, R., and Fisk, M. E. The extent of edema fluid formation induced by a superficial burn. Am. J. Physiol., 1930, 95, 325.

13. Harkins, H. N., Shift of body fluids in severe burns. Proc. Soc. Exper. Biol. and Med., 1934, 31, 994.

Experimental burns. I. The rate of fluid shift and its relation to the onset of shock in severe burns. Arch. Surg., 1935, 31, 71.

The bleeding volume in severe burns. Ann. Surg., 1935, 102, 444.

14. Underhill, F. P., Carrington, G. L., Kapsinow, R., and Pack, G. T., Blood concentration changes in extensive superficial burns, and their significance for systemic treatment. Arch. Int. Med., 1923, 32, 31.

15. Beard, J. W., and Blalock, Alfred, Experimental shock. VIII. The composition of the fluid that escapes from the blood stream after mild trauma to an extremity, after trauma to the intestines and after burns. Arch. Surg., 1931, 22, 617.

16. Underhill, F. P., and Fisk, M. E., Studies on mechanism of water exchange in animal organisms. The composition of edema fluid resulting from a superficial burn. Am. J. Physiol., 1930, 95, 330.

17. Roome, N. W., Keith, W. S., and Phemister, D. B., Experimental shock: The effect of bleeding after reduction of the blood pressure by various methods. Surg., Gynec. and Obst., 1933, 56, 161.

18. Harkins, H. N., Shock due to freezing. I. Shift of body fluids and associated blood concentration changes. Proc. Soc. Exper. Biol. and Med., 1934, $32,432$.

Harkins, H. N., and Hudson, J. E., Shock due to freezing. II. Composition of edema fluid. Ibid., 434.

Harkins, H. N., and Harmon, P. H., Experimental freezing: Bleeding volume, general and local temperature changes. Ibid., 1142.

19. Harkins, H. N., Acid-base and salt regulation in the blood. I. The chemical and physiological consequences of experimental acidosis. Univ. of Chicago Science Series, 1928-29, 7, 469.

Harkins, H. N., and Hastings, A. B., A study of electrolyte equilibrium in the blood in experimental acidosis. J. Biol. Chem., 1931, 90, 565.

20. Folin, O., Two revised copper methods for blood sugar determinations. J. Biol. Chem., 1929, 82, 83.

21. Eisenman, A. J., A note on the Van Slyke method for the determination of chlorides in blood and tissue. J. Biol. Chem., 1929, 82, 411.

22. Koch, F. C., and McMeekin, T. L., A new direct nesslerization micro-Kjeldahl method and a modification of the Nessler-Folin reagent for ammonia. J. Am. Chem. Soc., 1924, 46, 2066. 